\title{
Tackling Problem-Solving Through the Curriculum and Community Enterprise for Environmental Restoration Project
}

\author{
Lauren Birney $^{1, *}$ \& Denise M. McNamara ${ }^{2}$ \\ ${ }^{1}$ Pace University, USA \\ ${ }^{2}$ The College of Staten Island, USA \\ *Correspondence: School of Education, Pace University, USA. Tel: 1-212-346-1889x11889. E-mail: \\ lbirney@pace.edu
}

"Discovery consists of seeing what everyone else has seen and thinking what no one else has thought" Jonathan Swift (1667-1745)

Received: April 3, 2021

Accepted: May 23, $2021 \quad$ Online Published: July 22, 2021

doi:10.5430/jct.v10n3p1

\author{
URL: https://doi.org/10.5430/jct.v10n3p1
}

\begin{abstract}
The aim of this study is to showcase the use of incorporating problem-solving in a multifaceted, long-term investigation. New York Harbor and its estuaries are undergoing a major revitalization due to the efforts of the Curriculum and Community Enterprise for Environmental Restoration Project. Comprised of a network of local educational and business partnerships, students who have been historically underrepresented in the S.T.E.M. field are given the opportunity to delve into environmental restoration in their local communities and strategize, analyze and evaluate environmental challenges to achieve success in problem-solving. The restoration of a sustainable environment is reliant upon innovative responses to the challenges posed. Problem-solving allows the students to use advanced thinking ability and it can also be the driving force of change. The project has resulted in a deeper understanding of local environmental restoration efforts and a stronger commitment to actionable plans for the future.
\end{abstract}

Keywords: problem-solving, environmental restoration, sustainability

\section{Introduction}

In a recent series on the History Channel, "The Men Who Built America" (David, Reams, Palmer, Counsman \& Fields, 2012), an abstruse conflict was presented. Two of the American pioneers of the Industrial Age were at odds with one another. Arguably driven by greed, Cornelius Vanderbilt and his vast railroad empire became a nemesis for John Rockefeller, the oil magnate. When Rockefeller needed a way to transport his oil throughout the United States, he relied on Vanderbilt's railroad system. In turn, Vanderbilt raised the price of the freight to a then exorbitant rate. Faced with financial disaster, Rockefeller relied on his problem-solving skills to outwit his saboteur. Sidestepping the railroad system completely, Rockefeller built a pipeline system to transport his oil throughout the country, and thus saved his fortune, and his status as one of the great entrepreneurs of the $20^{\text {th }}$ Century (Lipson, 2014). It is worth noting that Rockefeller did not devise the pipeline. That honor goes to Byron Benson (1832-1888). However, through the method of problem-solving, Rockefeller was able to use existing technology to his advantage.

As we enter the second decade of the $21^{\text {st }}$ Century, many educators are still grappling with the " $211^{\text {st }}$ Century Skills" needed by today's students. As outlined in the Glossary of Education Reform (2016), The term $21^{\text {st }}$-century skills refer to a broad set of knowledge, skills, work habits, and character traits that are believed-by educators, school reformers, college professors, employers, and others - to be critically important for success in today's world. Generally speaking, $21^{\text {st }}$-century skills can be applied in all academic subject areas, and in all educational careers, and civic settings throughout a student's life. Highlighted skills include problem-solving, critical thinking, and being 
able to communicate findings as essentially $21^{\text {st }}$-century competencies (Yang, Chuang, Li \& Tseng, 2013).

Problem-solving is the ability to provide a solution to an issue that is more complex than straightforward. Most times, it is an issue that is multifaceted and the solution is elusive and multifarious. In terms of issues that relate to Science, Technology, Engineering, and Mathematics (S.T.E.M.), problem-solving is an intrinsic component in each and every issue. The process of acquiring knowledge as opposed to accumulating facts is the key to the process of problem-solving. There are many facets of problem-solving and as such, a solution can be discovered through a plethora of explorations. In the 1960s, a general problem-solving model was developed and utilized in both academic and corporate training situations. Problem-solving was taught as a "content-free" thinking skill and applied to a variety of situations.

In essence, the problem-solving model of the 1960s resembles the "scientific method" which was utilized in science education settings. The "scientific method" includes the following steps which mirror those used in problem-solving:

- identifying a problem

- brain-storming to determine the number of possible solutions

- testing, and retesting a solution for reliability

- evaluating the results

- reporting the outcomes

In education, these models were one source of the "inquiry" curriculum movement, which led to new curricula such as "new math" (Foshay \& Kirkley, 2003) in the 1960s. Inquiry has always been a part of education and was introduced in the United States by John Dewey through his constructivist approach to education (Dewey, 1902). The main activity in a constructivist approach to learning is solving problems (UCD Teaching, and Learning, 2013). Through the University of Chicago's Laboratory School, which was established by Dewey in 1896, "learning through doing" was initiated. Through this model, students continue to be presented with real-world situations and challenges and are tasked with applying their curiosity, and problem-solving skills to meet these challenges. This educational philosophy is in sharp contrast to the Socratic Method, which was typical of the time, and was an integral part of American education through the 1950s. The Socratic Method begins by asking a question and then posing further questions in response to student answers (Peterson, 2009). Considered as passive on the part of the student, its popularity began to wane in the late 1950s as the primary method of education. A critical event that triggered a revolution in American education was the launching of Sputnik (1957) by the Russians, especially education in the fields of science and mathematics. American children were seen as having an inferior education to Russian children, and an outcry for immediate change resulted in the resurgence of the "inquiry" curriculum. Instead of being given a set of facts and figures to memorize and regurgitate, students were being presented with problems that they were asked to solve using their ability to think critically and apply the knowledge to address the challenge. As stated by Daniel J. Boorstin in The Americans: The Democratic Experience (1973), "Never before had so small and so harmless an object created such consternation".

\section{Problem-Solving for Sustainability}

Problem-solving requires systemic thinking; a mental toolbox that is able to utilize existing knowledge and repurpose it in a unique way to achieve the desired outcome, tackle a new problem, or design a unique solution to universal challenges found in the community. The need for a scientifically literate citizenry is paramount in facing the current and future environmental issues of sustainability. Citizens who possess well-developed critical thinking and problem-solving skills are needed to meet the needs of these environmental challenges (National Research Council, 2012). Effective environmental education to raise public awareness is possible through the application of the Problem-Based Learning (PBL) method, which enhances environmental education by teaching students how to find and solve problems. By using the PBL method students are invited to think about existing problems in their community and possible methods of solution. It was also found, that learning with PBL was not learning to remember but was instead an invitation to think and analyze. In this setting, the teacher assumes the role of guide to help monitor monitors students' thinking patterns (Rachman, Sugimaru \& Matsumoto, 2020).

Linking Problem-Based Learning, Place-Based Learning, and the Next Generation Science Standards is an approach to science education that enhances student appreciation for the importance of science in their own lives and communities, engages students in the practice of science, and increases student confidence in communicating scientific topics (Engels, Miller, Squires, Jennewein, \& Eitel, 2019). One of the most dynamic and enduring efforts 
to incorporate these methods is called the Curriculum and Community Enterprise for Environmental Restoration Project, known as CCERS + BOP henceforth. Through its community-based environmental curriculum, the project has linked formal and informal educational setting to create a replicable model of true place-based S.T.E.M. education. Research indicated that curriculum creates opportunities for students to work in the field in their communities, utilizing multiple facets of STEM learning, including making observations, collecting data using scientific instruments, and organizing data on the digital platform (Caref, Rex, Lederberg \& Moore, 2019). Focusing on a real project helps students learn "to think deeply and critically about their world" (Behizadeh, 2014), while also allowing students to construct knowledge on their own terms without simply following their teacher's instructions (Martinich, 2006). Taking problem-solving skills further, research states that problem-solving is embedded in the social constructivist view of teaching and learning and promotes self-regulated learning that is enhanced through exploration and cooperative social activity (Savery \& Duffy, 1995).

\section{The Evolution of the CCERS + BOP + STEM + C Project}

Prior to the establishment of the Curriculum and Community Enterprise for Restoration Science, a number of independent organizations were involved in the revitalization of New York Harbor and its watershed. Considered the most urban estuary on Earth, it is a 16,300 square mile watershed that is home to more than with more than 200 fish species and includes habitats such as wetlands, shorelines and coastal forests (NYNJbaykeeper.org, 2020). Organizations such as the NY-NJ Baykeeper, the New York Harbor Foundation, and the Nature Conservancy initiated awareness of the contaminated condition of the waterways that surround the City of New York. However, it was only through the formation of complex partnerships with community groups, researchers, and university leaders that a massive and sustainable effort to clean the waterways was instituted.

The Billion Oyster Project (BOP) is a citizen science restoration project, existing in New York Harbor since 2008. It was inspired by the Chesapeake Bay Oyster Recovery Project which was successful in replanting approximately 6.7 billion oysters in the bay. BOP has its origins in the restoration activities started by the faculty and students at the Urban Assembly Harbor School located on Governors' Island in New York Harbor. The goal of the Billion Oyster Project is to restore 1 billion oysters to New York Harbor by the year 2035.

In August 2014, the National Science Foundation (Award \#1440869) awarded \$5,374,972.00 to the Curriculum and Community Enterprise for New York Harbor Restoration in New York City Public Schools Project (CCERS). The Billion Oyster Project combined with the Curriculum and Community Enterprise for Restoration Science Project to form an expansive place-based environmental education effort conducted in the schools in New York City (Birney \& McNamara, 2017). This added more structure and several new components to the Billion Oyster Project by creating a model of curricula and community enterprise within the New York City public school system. Middle school students attending New York City schools in underserved communities were selected to study the New York Harbor and its impact on the community within the harbor and surrounding it. Historical, geological, and environmental impacts are explored with the intent of eliciting empathy for the restoration of the native oyster population while instilling motivation for stewardship of the harbor, heightened motivation in STEM disciplines, and a possible pipeline to future career paths. Students experience higher levels of engagement and take a deeper approach to learning when they are able to apply what they are studying to address a real-world problem (Lombardi, 2007).

To accomplish these goals, the BOP CCERS project engages students in the restoration of the native oyster (Crassostrea virginica) habitats in New York Harbor through the combination of field research and classroom investigations. The project is based on five separate but interconnected pillars:

(1) Teacher education curriculum - created by CCERS staff and content experts in the partnership

(2) Student learning curriculum - created by CCERS staff and classroom teachers and implemented in the NYC middle school classrooms

(3) Digital platform for resources - housing lessons, units, empirical data from the field stations, and research papers

(4) After-school STEM program - conducted through the joint efforts of Good Shepard Services, the New York Academy of Science, and the NYC Department of Education

(5) Public exhibits - at the Hudson River Project headquarters and the New York Aquarium

The project is based on cross-sector partnerships with several stakeholders including Pace University, the New York

City Department of Education, the Columbia University Lamont-Doherty Earth Observatory, the New York Academy of Sciences, the New York Harbor Foundation, Good Shepherd Services, and the Hudson River Project 
among others. As with many community-based partnerships (Minkler, Vásquez, Tajik, \& Petersen, 2006), the partners demonstrate a strong commitment to collaborate with all stakeholders as well as the other partners in the project. To this end, the partners in the BOP-CCERS Project were carefully selected so that each could bring their unique attributes and specializations to the table. One of the ways to ensure that this authentic and connected learning can take place is by leveraging strong community partnerships to provide real-world learning to students in middle and high schools (Gross, et al., 2015).

In February 2018, the National Science Foundation (Award \#759006) awarded an additional $\$ 2,000,000.00$ to the Curriculum and Community Enterprise for a Keystone Species in New York Harbor, also known as CCERS + STEM-C. In addition to the original model and its areas of implementation, the project is expanding its real-world problem-based curriculum model to focus on practices that increase student motivations and capacities to pursue careers in fields of science, technology, engineering, or mathematics (STEM). Continuing to focus on New York Harbor and oyster restoration, students and teachers in grades K-12 conduct field research in support of restoring native oyster habitats.
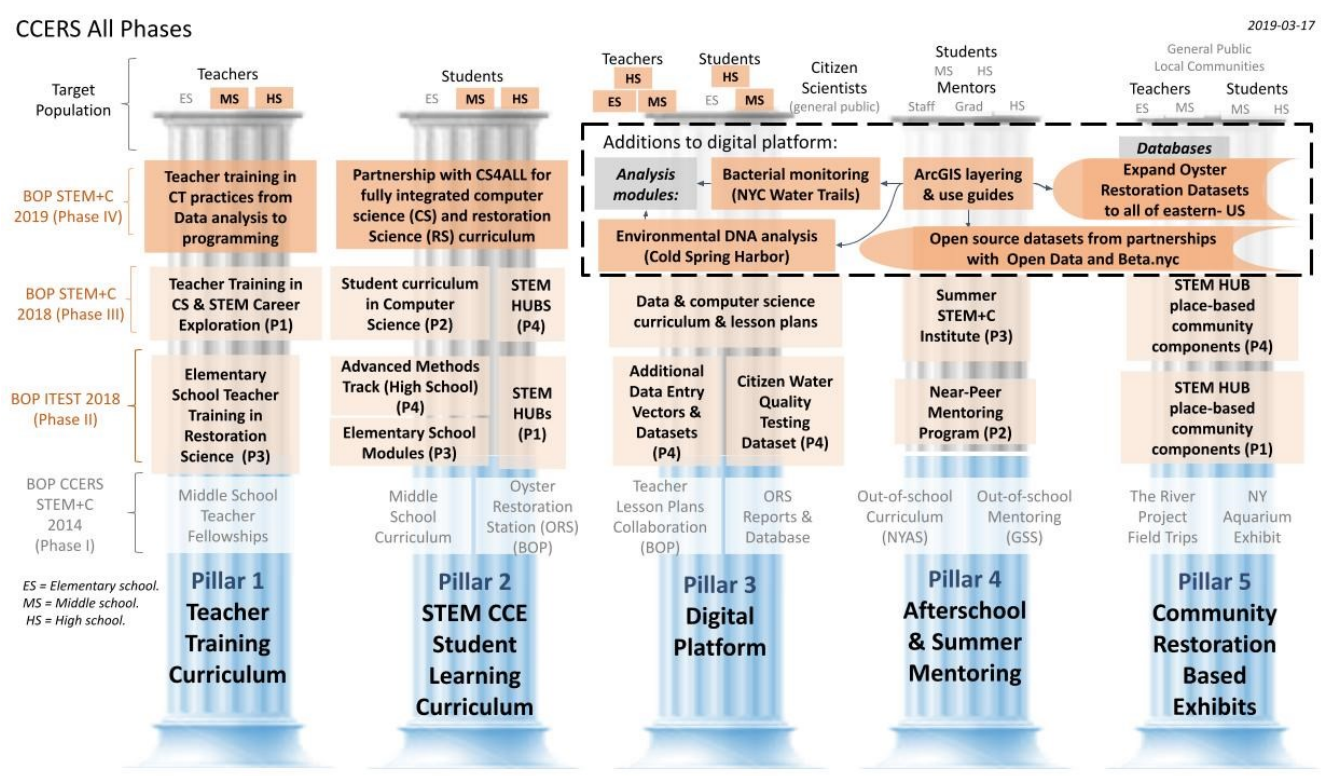

Figure 1. The Five Pillars of the Curriculum and Community Enterprise for Restoration Science + STEM-C

The project model has been expanded to include several correlated pieces that include a teacher restoration science curriculum with components for elementary and middle school teachers; a student learning curriculum for elementary and middle school students; an enhanced digital platform for project resources and data collection; an aquarium exhibit at the New York City Aquarium; an after-school STEM mentoring program and a near-peer mentoring program; community-based restoration science hubs and advanced methods of laboratory analysis in restoration science for high school students including:

1. Genetic barcoding (species ID)

2. Environmental DNA sampling and analysis

3. Bacterial monitoring

4. Water chemistry analysis 


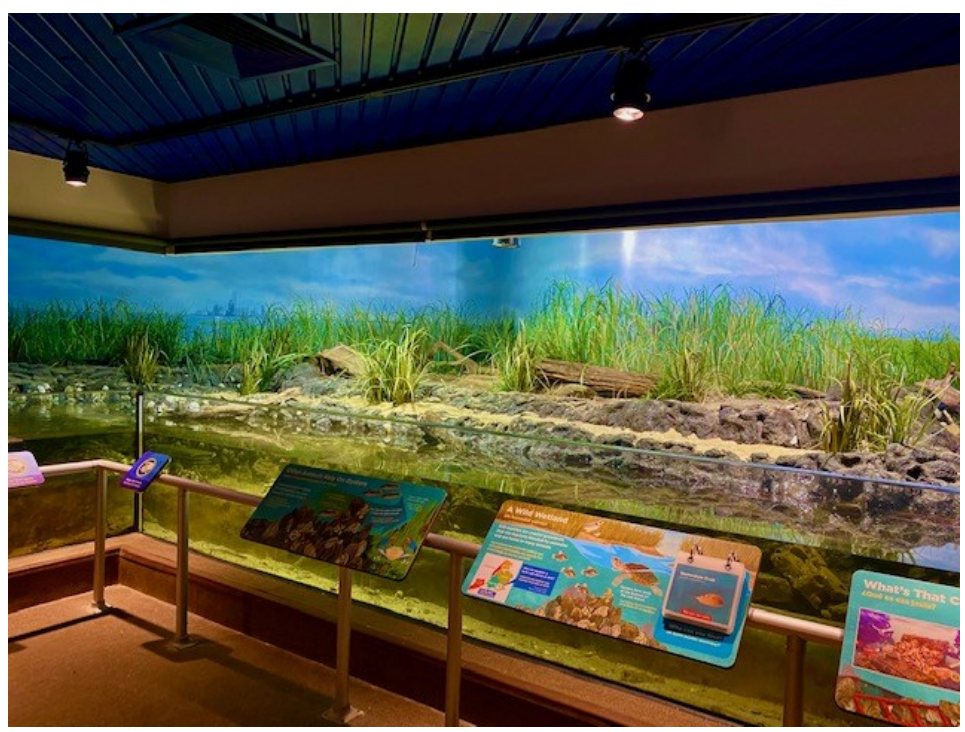

Figure 2. Exhibit of the BOP CCERS + STEM-C Project at the New York Aquarium

Table 1. Timeline of the Major Accomplishments of the Project

\begin{tabular}{|c|c|c|}
\hline By August 2015 & By August 2018 & By August 2020 \\
\hline 11.5 million oysters grown in New York & 25 million oysters grown in New & 47 million oysters grown in New \\
\hline Harbor & York Harbor & York Harbor \\
\hline 1.05 acres of reef area restored & 2.5 acres of reefs restored & 4.8 acres of reefs restored \\
\hline $\begin{array}{l}\text { Approximately } 93,600 \text { pounds of oyster shell } \\
\text { recycled }\end{array}$ & $\begin{array}{l}\text { Approximately } 1 \text { million pounds of } \\
\text { oyster shells recycled }\end{array}$ & $\begin{array}{l}\text { Approximately } 1.6 \text { million pounds } \\
\text { of oyster shells recycled }\end{array}$ \\
\hline $\begin{array}{l}\text { The oysters have filtered approximately } \\
10.9 \text { trillion gallons of New York Harbor } \\
\text { water }\end{array}$ & $\begin{array}{l}\text { The oysters have filtered } \\
\text { approximately } 25 \text { trillion gallons of } \\
\text { New York Harbor water }\end{array}$ & $\begin{array}{l}\text { The oysters have filtered } \\
\text { approximately } 50 \text { trillion gallons } \\
\text { of New York Harbor water }\end{array}$ \\
\hline $\begin{array}{l}\text { The oyster filtration has removed } \\
\text { approximately } 6.75 \text { million pounds of nitrogen }\end{array}$ & $\begin{array}{l}\text { The oyster filtration has removed } \\
\text { approximately } 16 \text { million pounds of } \\
\text { nitrogen }\end{array}$ & $\begin{array}{l}\text { The oyster filtration has removed } \\
\text { approximately } 30 \text { million pounds } \\
\text { of nitrogen }\end{array}$ \\
\hline
\end{tabular}

Augmenting the original environmental restoration project by focusing on career and technical education pathways, the STEM $+C$ Phase supports the original goals through the development and implementation of (4) project pillars.

Pillar 1: Teacher Training with Computer Science, Data Science, and STEM Career Exploration

Pillar 2: Student Curriculum with Computer Science, Data Science, and STEM Career Exploration

Pillar 3: Summer STEM Institute for Middle and High School Students at Pace

Pillar 4: Community Based Restoration Science Hubs ("STEM Hubs")

The STEM $+C$ phase will continue through August of 2022 and will continue to target students in low-income neighborhoods comprised of high populations of English language learners and students that are underrepresented in STEM fields and education pathways. A major enhanced focus of the project is engaging these students to help create a more diverse STEM workforce. The persistent call for $21^{\text {st }}$-century skill development includes learning and innovation skills derived from problem-solving and critical thinking, which will help New York City Public school students to fill the STEM jobs of the future (Trilling \& Fadel, 2009). The project directly involves 97 schools, over 300 teachers, and approximately 15,000 K-12 students.

The Billion Oyster Platform now contains, but is not limited to:

- 200 Oyster Reef Stations 
- 100 minutes of educational videos

- 70 Symposium projects

- 6,000 students

\section{How CCERS + BOP + STEM + C Incorporated Problem-solving}

Paramount to successful problem-solving is the ability to define the problem and follow with actionable steps to test theoretical solutions. The BOP-CCERS Project capitalizes on the most applicable concepts and practices of the K-12 Computer Science Framework, with an emphasis on those areas where Computer Science integrates seamlessly with New York State P-12 Science Learning Standards, specifically the Core Concepts of Data.

Interpretation, and Analysis, and the following Core Practices:

\section{- Define problems}

S1. Ask questions and define problems. (National Research Council, 2012)

M1. Make sense of problems and persevere in solving them. (Common Core Math Standards)

CS3. Recognizing and Defining Computational Problems

\section{- Use computational thinking}

S5. Use mathematics and computational thinking. (National Research Council, 2012)

CS3. Recognizing and Defining Computational Problems

CS4. Developing and Using Abstractions

CS5. Creating Computational Artifacts

\section{- Communicate with data}

S4. Analyze and interpret data. (National Research Council, 2012)

CS7. Communicating About Computing

Using these tools to create a viable environmental restoration curriculum, the infrastructure for developing and refining problem-solving skills has been established. The depository for all of the information needed to motive problem-solving conceptions is the BOP Digital platform. Human thought is extended by combining computational thinking with problem-solving situations and has become an indispensable part of our everyday lives and work (Barr, Harrison \& Conery, 2011). Computational thinking is a problem-solving process composed of four stages:

- Decomposition - Breaking a problem into manageable chunks to make it easier to solve.

- Pattern Recognition - Seeing a generalized view of the problem; trends or regularities in the data

- Abstraction - Finding the general principles that generate the patterns in the data

- Algorithm design - Developing the step-by-step instructions to solve this problem and others

Research has shown (Psycharis \& Kallia, 2017) several positive outcomes on students' problem-solving skills, reasoning skills, and self-efficacy with the incorporation of computational thinking in mathematics and science. These findings helped to shape the evolving structure of the BOP-CCERS Project and the inclusion of computational thinking through the Computer Science for All initiative in the New York City Department of Education.

\section{Problem-Solving through BOP-CCERS + STEM C Unit}

By introducing and dissecting a unit from the BOP CCERS + STEM-C Project, the skill of problem-solving embedded in a real-world sustainable environmental project can be seen. The Nitrogen Cycle Investigation is one of the units found on the BOP Digital Platform. This open-access site is available to the students and teachers involved in the program. The National Science Foundation task force on cyber-learning (National Science Foundation, 2008) recommends that a "platform perspective" should be instilled through shared, interoperable designs of hardware, software and services - into NSF's cyber-learning activities.

The Billion Oyster Project Digital Platform is comprised of five distinct but dynamic sections all containing valuable resources: 
- Restoration - this section of the platform contains the dashboard which maps all of the Oyster Research Stations that are sprinkled throughout New York Harbor and surrounding estuaries. Within each of the Oyster Research Stations can be found the data gathered during each of the site visits.

- Curriculum - this section holds the key to unlock all of the problem-solving skills that are needed by the students and teachers. Through the contributions of environmental scientists, teachers, and citizen scientists, a rich trove of lessons and units of study can be tapped for use in the classroom or in the field. Content areas such as science, mathematics, map skills, geography, history, and engineering are enhanced with technology to form robust teaching and learning resource.

- Research - it is in this section of the platform that the results of the students' research and discoveries are housed. Student-created research publications and poster presentations are on display for both recognition, and as exemplars for other students who will follow.

- Community - Students, Teachers, Citizen Scientists, Researchers, Parents, Administrators. Etc.

- Events - BOP Symposium, Fundraising Events, etc.

The units and lessons are continually being revised and improved through the use and teacher feedback in the classroom and the field. The units include Introductory Lessons, Marine \& Maritime Career Lessons, New York Harbor Populations Investigations, Near Peer Career Panels, New York's Urban Ecosystem Lessons, Oyster Tank Investigation, Oysters \& Organisms Lessons, Nitrogen Cycle Investigation, Steward-shed Investigation, Water Quality Lessons, Living Breakwaters Lessons, and more.

Through the presentation of each lesson an increasing understanding of the nitrogen molecule is developed. From its chemical structure and characteristic qualities to its presence in New York Harbor and impact on the environment, students are lead on a journey that includes:

- Structural manipulation - Students are tasked with building molecular models of an ammonia molecule, a nitrite ion, a nitrate ion, and a nitrogen gas molecule. By using their molecular models and their chemical knowledge, they develop an understanding of the word nitrogen and its multiple usages (as a type of atom, and as a category of nitrogen-containing molecules).

- Nitrogen Transformation - Students are asked to study a series of oyster tank diagrams containing aquatic organisms and compare and contrast the transformation of nitrogen in the organisms in the tank. Students then determine the cyclical events that are occurring in the transformations and illustrate their findings.

- Harmful effect of ammonia and nitrates - Students review several reference sources and evaluate the materials for possible methods of protecting the oyster tanks from ammonia or nitrite poisoning. Based on that analysis, the students use their problem-solving skills to determine the best method for cycling the classroom tank. Informed methods for determining the best possible conditions for developing a community of nitrifying bacteria are entered into a research journal.

- Nitrogen Pollution - Students read "Your Chicken Nuggets Are Killing Your Crab Cakes," an article about the connections between agriculture and nitrogen pollution in waterways. Students map the movement of nitrogen across the United States via the food system and discuss how (or whether) the nitrogen map would change if people stopped eating chicken nuggets. Students are able to identify major sources of or nutrient pollution of estuaries, translate textual information into map-based representations and speculate about a hypothetical case.

- Neighborhood Nitrogen Mapping - Students use a library of resources in the classroom to determine the sources of nitrogen in their neighborhood that eventually pollute the New York Harbor estuary. Students then transpose nitrogen source information in text and diagrams and design a map of nitrogen concentrations in the various areas of New York Harbor.

- Using nitrogen test strips - Students practice measuring the ammonia, nitrite, and nitrate in various water samples using the nitrogen testing strips for the regular monitoring of the ammonia, nitrite and nitrate level in the classroom tank and in their fieldwork.

- Using the digital platform to study nitrogen throughout the New York Harbor Estuary - Students access NYC ammonia and nitrates data from https://platform.bop.nyc in order to compare their map of nitrogen concentrations and explore their questions about nitrogen beyond the classroom tank and beyond their own ORS (Oyster Research Stations). 

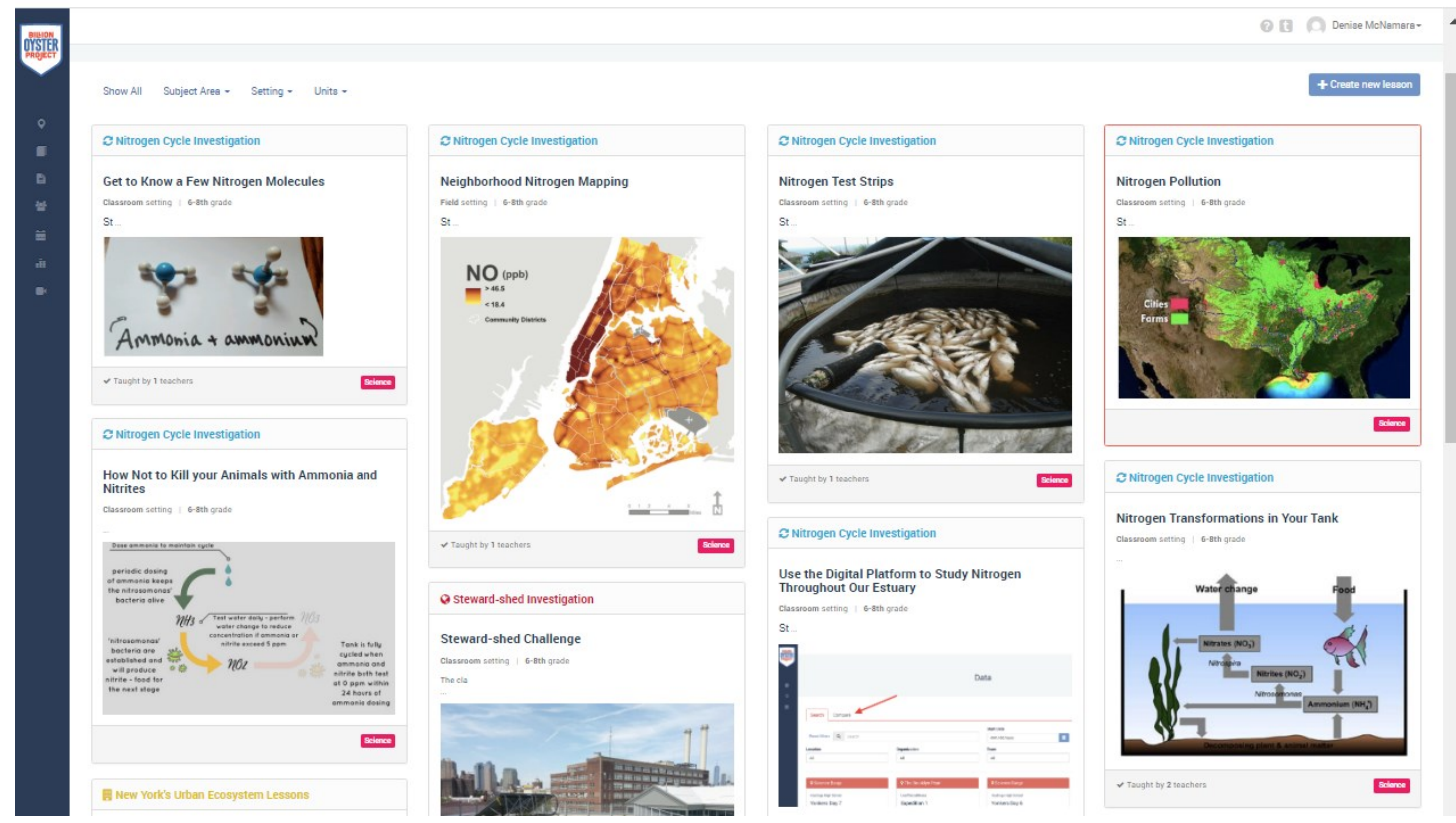

Figure 3. Snapshot of the Lessons on the Nitrogen Cycle on the BOP Digital Platform (https://platform.bop.nyc/)

\section{Conclusion/Summation}

The essential component of instilling and nurturing problem-based skills is teaching students how to think and reason. According to Bloom's taxonomy of Educational Objectives, (revised edition, 2001), there are six major categories: remember, understand, apply, analyze, evaluate and create. The highest order of thinking is to create original work (Armstrong, 2010). The precursor to the remainer of the hierarchy is the basis of all other thinking - to remember.

\section{Bloom's Taxonomy}

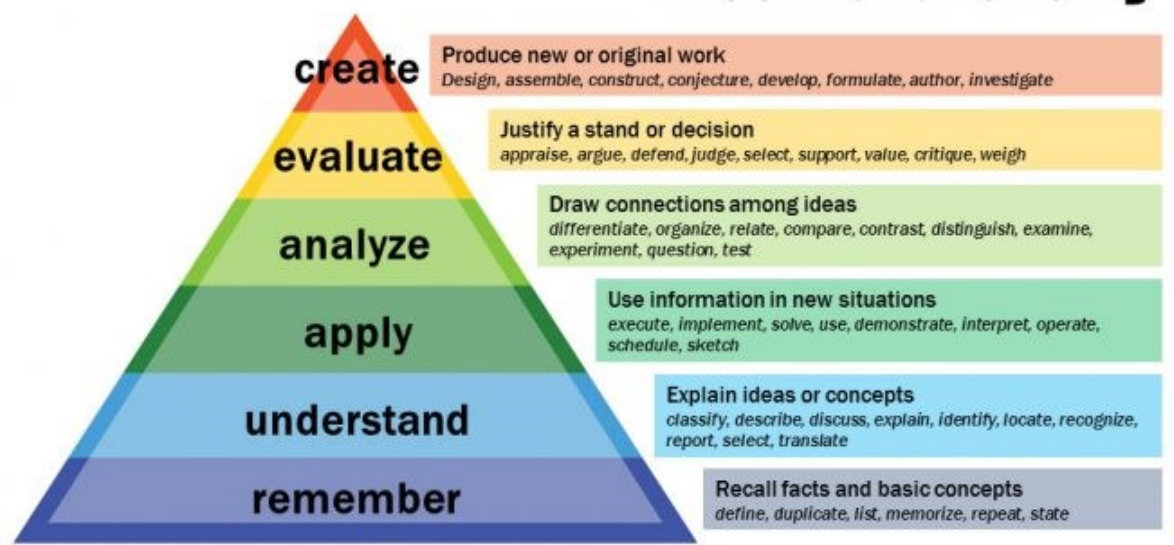

(Q) - Danderbilt University Center for Teaching

Figure 4. Bloom's Taxonomy of Educational Objectives

The BOP-CCERS + STEM C Project has provided the venue for students in the New York City public school system the ability to look at their home environment as a breeding ground for sustainable development in their local urban setting. Through the in-class, after-school, and field experiences in which the students participate, a building of knowledge of their environment and the skills needed to apply this knowledge to effect change has been established.

The BOP Digital Platform provides a plethora of information for and about this project, but none is as telling as the section containing publications and posters. Herein lie the students' original work which has been created through 
the combination of knowledge of the New York Harbor and its estuaries, challenges needed to be addressed to ensure sustainable restoration of the harbor, and innovative ideas that are needed to elucidate and possibly resolve the problem. Examples of the students' creative work focus on problem-solving for a sustainable future for New York Harbor. Publication titles include works such as, "Best Oyster Cage Designs for Harsh Conditions", "Development of a Protocol to Assess the Relative Habitat Values of Urban Shorelines in New York-New Jersey Harbor", and, "How can we propose a new design for CSOs (combined Sewer Overflows) to prevent sewage from going into our waters?". This evidence indicates that students who are involved in the BOP CCERS + STEM C Project are engaged in problem-solving and creative thinking skills beyond the norm.

One of the highlights of the BOP CCERS + STEM C Project is the yearly Symposium held on Governors' Island, which is situated in New York Harbor, nestled between the Hudson and East Rivers. The symposium is held at the end of the school year and is a showcase for the students from across the city to share the work they have created and present to their teachers, peers, parents, citizen scientists, and researchers. (the symposium was held virtually in 2020 due to the pandemic). These students have worked alongside their teachers, researchers, and other citizen scientists and grappled with real-world environmental challenges that must be resolved for a sustainable future. Research has shown that this type of problem-based learning is significantly more effective than traditional instruction on students' performance in authentic situations and long-term knowledge retention (Strobel \& van Berneveld, 2009).

"Process, problem-solving, knowing how to think rather than what, and curiosity and creativity are intrinsic and vital skills for science, education and innovation in our modern time. When you know how to think, it powers you far beyond those who only know what to think." Neil deGrasse Tyson

\section{References}

Armstrong, P. (2010). Bloom's Taxonomy, Vanderbilt University Center for Teaching. Retrieved 12 March, 2021 from https://cft.v, anderbilt.edu/guides-sub-pages/blooms-taxonomy/

Barr, D., Harrison, J., \& Conery, L. (2011). Computational Thinking: A Digital Age. Learning and Leading with Technology, 38(6), 20-23. https://eric.ed.gov/?id=EJ918910

Behizadeh, N. (2014). Enacting problem-posing education through project-based learning. The English Journal, 104(2), 99-104. https://www.jstor.org/stable/24484422

Birney, L., \& McNamara, D. (2017). Authentic Community Based Learning in New York City: An Holistic Model using the Billion Oyster Project, and Community Enterprise for Restoration Science. Journal of Education and Human Development, 6(4), 1-15. https://doi.org/10.15640/jchd.v6n4al

Boorstin, D. J. (1973). The Americans: The Democratic Experience. Vintage Books Edition, Random House. https://doi.org/10.1080/03612759.1973.9947087

Caref, E., Rex, M., Lederberg, A., \& Moore, G. (2018). If you give a kid an oyster: Reflection on Collaborations in Place-Based STEM Education through Oyster Restoration in New York City. Journal of STEM Outreach, 1(2), 24-34. https://doi.org/10.15695/jstem/v1i1.13

David, S., Reams, P., Palmer, K., Counsman, R., \& Fields, E. (2012). The Men Who Built America, Santa Monica. Calif: A \& E Television Networks, LLC, Santa Monica, Calif.: Distributed by Lionsgate Entertainment.

Dewey, J. (1902). The School and Society and the Child and the Curriculum. Centennial Publications of the University of Chicago, ILL ISBN 10:1-4209-3801-0.

Engels, M., Miller, B., Squires, A., Jennewein, J. S., \& Eitel, K. (2019). The Confluence Approach: Developing Scientific Literacy through Project-Based Learning, and Place-Based Education in the Context of NGSS. Electronic Journal of Science Education, 23(3), 33-58.

Foshay, R., \& Kirkley, J. (2003). Principles for teaching problem solving. Technical paper 4. Resource document. PLATO Learning, Inc. Retrieved Oct. 2020 from http://files.eric.ed.gov/fulltext/ED464604.pdf

Great Schools Partnership (2014). The Glossary of Education Reforms. 482 Congress Street, Suite 500 | Portland, ME 04101. Retrieved from greatschoolspartnership.org

Gross, J. M. S., Haines, S. J., Hill, C., Francis, G. L., Blue-Banning, M., \& Turnbull, A. P. (2015). Strong school-community partnerships in inclusive schools are "Part of the fabric of the school. We count on them." School Community Journal, 25(2), 9-34. 
Lipson, J. (2014). Lessons from Vanderbilt and Rockefeller: Know Your 'One Big Thing', Forbes. Retrieved from 9 January, 2014 from https://www.forbes.com/sites/jesselipson/2014/01/09/lessons-from-vanderbilt-and-rockefeller-know-your-one-b ig-thing/\#3e81195e5448

Lombardi, M. (2007). Authentic learning for the 21st Century: an overview. Educause Learning Initiative, ELI Paper 1. Retrieved from http://net.educause.edu/ir/library/pdf/ELI3009.pdf

Martinich, J. A., Solarz, S. L., \& Lyons, J. R. (2006). Preparing students for conservation careers through project-based learning. Conservation Biology, 20(6), 1579-1583.

Minkler, M., Vásquez, V., Tajik, M., \& Petersen, D. (2006). Promoting Environmental Justice through Community-Based Participatory Research: The Role of Community, and Partnership Capacity. Health Education \& Behavior, 35(1), 119-137. https://doi.org/10.1177/1090198106287692

National Research Council (2012). A Framework for K-12 Science Education: Practices, Crosscutting Concepts and Core Ideas. Washington, DC: The National Academies Press. https://doi.org/10.17226/13165

National Science Foundation (2008). Fostering Learning in the Networked World: The Cyberlearning Opportunity and Challenge. Report of the NSF Task Force on Cyberlearning, cyberlearning@nsf.gov

New York - New Jersey Baykeeper (2020). The NY-NJ Harbor Estuary. Retrieved from https://www.nynjbaykeeper.org/

Peterson, E. (2009). Teaching to Think: Applying the Socratic Method outside the Law School Setting. Journal of College Teaching and Learning, 5(6), 83-88. https://doi.org/10.19030/tlc.v6i5.11455

Psycharis, S., \& Kallia, M. (2017). The effects of computer programming on high school students' reasoning skills and mathematical self-efficacy, and problem solving. Instructional Science, 45(5), 583-602. https://doi.org/10.1007/s11251-017-9421-5

Rachman, I., Sugimaru, C., \& Matsumoto, T. (2020). Use of Problem-Based Learning (PBL) Model to Improve Learning Outcomes in Environmental Education. Journal of Environmental Science and Sustainable Development, 1(3), 114-141. https://doi.org/10.7454/jessd.v3i1.1039

Savery, J. R., \& Duffy, T. M. (1995). Problem-based learning: An instructional model and its constructivist framework. Educational Technology, 35(5), 31-38.

Strobel, J., \& van Barneveld, A. (2009). When is PBL more effective? A meta-synthesis of meta-analyses comparing PBL to conventional classrooms. Interdisciplinary Journal of Problem-based Learning, 3(1), 44-58. https://doi.org/10.7771/1541-5015.10466

Trilling, B., \& Fadel, C. (2009). 21st Century Skills: Learning for Life in Our Times. San Francisco, CA: John Wiley $\&$ Sons.

UCD Teaching and Learning (2013). Constructivism, and Social Constructivism in the Classroom Retrieved from http://www.ucdoer.ie/index.php?title=Education_Theory/Constructivism_and_Social_Constructivism_in_the_C lassroom

Yang, Y. C., Chuang, Y., Li, L., \& Tseng, S. (2013). A blended learning environment for individualized English listening, and speaking integrating critical thinking. Computers \& Education, 63, 285-305 https://doi.org/10.1016/j.compedu.2012.12.012

\section{Copyrights}

Copyright for this article is retained by the author(s), with first publication rights granted to the journal.

This is an open-access article distributed under the terms and conditions of the Creative Commons Attribution license (http://creativecommons.org/licenses/by/4.0/). 